\title{
Comparative study of fungal cell disruption-scope and limitations of the methods
}

\author{
Magdalena Klimek-Ochab • Małgorzata Brzezińska-Rodak • Ewa Żymańczyk-Duda • \\ Barbara Lejczak • Paweł Kafarski
}

Received: 6 June 2011 / Accepted: 29 August 2011 / Published online: 8 September 2011

(C) The Author(s) 2011. This article is published with open access at Springerlink.com

\begin{abstract}
Simple and effective protocols of cell wall disruption were elaborated for tested fungal strains: Penicillium citrinum, Aspergillus fumigatus, Rhodotorula gracilis. Several techniques of cell wall disintegration were studied, including ultrasound disintegration, homogenization in bead mill, application of chemicals of various types, and osmotic shock. The release of proteins from fungal cells and the activity of a cytosolic enzyme, glucose-6phosphate dehydrogenase, in the crude extracts were assayed to determine and compare the efficacy of each method. The presented studies allowed adjusting the particular method to a particular strain. The mechanical methods of disintegration appeared to be the most effective for the disintegration of yeast, $R$. gracilis, and filamentous fungi, A. fumigatus and P. citrinum. Ultrasonication and bead milling led to obtaining fungal cell-free extracts containing high concentrations of soluble proteins and active glucose-6-phosphate dehydrogenase systems.
\end{abstract}

The microbial world offers a variety of products important and useful for human life, including chemical intermediates, antibiotics, enzymes, and therapeutic agents. Some of them are produced by microbes and are excreted into the cultivation medium and easily isolated. In contradiction, isolation and canvassing of intracellular products often require complicated sequences of operations. This task usually starts from a cell disruption process. Disintegration of cells precedes the

M. Klimek-Ochab $(\bowtie) \cdot$ M. Brzezińska-Rodak •

E. Żymańczyk-Duda • B. Lejczak • P. Kafarski

Department of Bioorganic Chemistry,

Wroclaw University of Technology,

Wybrzeże Wyspiańskiego 27,

50-370, Wrocław, Poland

e-mail: magdalena.klimek-ochab@pwr.wroc.pl fractionating and purification of constituent of the cell structures and influences the quality of the final product (Savov et al. 2001). Various cell disruption methods have been developed to establish an efficient, low-cost, and effective release of intracellular products (Middelberg 1995; Geciova et al. 2002; Ho et al. 2008). The application of certain disintegration techniques depends on such cell properties as physical strength of the cell wall and intracellular location of the desired product (Sauer et al. 1989; Kuboi et al. 1995). Complete destruction of the microbial cell in a nonspecific manner is usually achieved by ultrasound disruption of the cell (Borthwick et al. 2005; Gogate and Kabadi 2009). This process can proceed via complete breakage of the individual cells, releasing all intracellular enzymes, or it can be shear-driven, where only the cell wall breaks and as a result only the enzyme present in the cell wall or periplasm will be released (Balasundaram and Pandit 2001). The mechanism of cell disruption is associated with the cavitation phenomena, shear stress developed by viscous dissipative eddies arising from shock waves produced by imploding cavitation bubbles (Middelberg 1995; Harrison 1991; Garcia 1993). Another mechanical method to damage microbial cell walls of different structures is bead milling, applied successfully in both laboratory and industrial scales (Doucha and Livansky 2008). Compounds are released from cells due to the action of circulating beads dispersed in the fluid (Middelberg 1995; Doucha and Livansky 2008; Heim et al. 2007). A bead mill can be operated either in batch (RicciSilva et al. 2000) or in a continuous recycling mode (Ho et al. 2008). For a large-scale disintegration of the biological material, the mechanical method (the high-pressure homogenizer) is usually used. High-pressure cell opening is achieved by passing them through an adjustable, restricted orifice discharge valve (Engler 1985; Hetherington et al. 1971; Keshavarz-Moore et al. 1990; Kelly and Muske 2004). 
Non-mechanical processes have also been designed as alternatives to mechanical techniques, but the process-scale application is a crucial limitation in this case (Yasotha et al. 2006; Joubert and Fleurence 2008; Denis et al. 2009). The advantages of the application of enzymes are gentle process conditions and their specificity (Middelberg 1995; Kitamura 1982; Taskova et al. 2006; Ablain et al. 2009). Unfortunately, enzymatic digestion of the cell wall may be too expensive when it is used in a large scale. Permeabilization or lysis of cells can be performed also by chemical treatment. Antibiotics, chelating agents, detergents, and solvents are capable of disintegrating the cells (Dean and Ward 1992; Al-Samarrai and Schmidt 2000; Corrado and Rodrigues 2004; Leuko et al. 2008; Doolan and Wilkinson 2009). These procedures rely on the selective interaction of the chosen chemicals with components of the membrane and allow proteins to seep through the cell wall. There are at least two physical procedures - osmotic shock and thermolysis - also used for cell disintegration (Chen et al. 2004; Tkac et al. 2004; Ren et al. 2007a, b). The application of two or more procedures combined with the cells wall disruption is also reported (Anand et al. 2007; Lim et al. 2008; Chaves-Lopez et al. 2009; Shynkaryk et al. 2009).

Most of the published articles were focused on the disruption of Escherichia coli (Gram-negative bacteria), Bacillus subtilis (spore-forming Gram-positive bacteria), or yeast (Saccharomyces cerevisiae or Candida utilis; Ho et al. 2008; Ren et al. 2007a; Anand et al. 2007; Lim et al. 2008; Chaves-Lopez et al. 2009; Shynkaryk et al. 2009; Fonesca and Cabral 2002; Agrawal and Pandit 2003). Literature data devoted to other microorganisms, especially fungi, are relatively scarce (Taubert et al. 2000), meaning that they are still a not fully explored source of intracellular compounds of possible industrial applications. Therefore, this report focuses on the rationally planned studies performed in order to elaborate effective disruption methods (both mechanical and non-mechanical) using Rhodotorula gracilis, Aspergillus fumigatus, and Penicillium citrinum as model objects.

\section{Materials and methods}

\section{Chemicals}

All chemicals were purchased from commercial suppliers: Difco, POCh, Sigma-Aldrich.

Fungal strains

R. gracilis (Rhodosporidium toruloides) DSM 4444, was from DSMZ, Germany. A. fumigatus was a kind gift from the University of Pavia, Italy. P. citrinum was a kind gift from the University of Opole, Poland.
Cultivation media

A. fumigatus and P. citrinum were cultivated on a potato dextrose broth (Difco). R. gracilis was cultivated on a malt extract peptone broth (Difco). Microbial cultivation media were prepared according to the instructions of the suppliers and autoclaved.

Cultivation methods

Fungi were cultivated in $250-\mathrm{mL}$ flasks containing $50 \mathrm{~mL}$ of the corresponding medium until the mid-log phase $\left(25^{\circ} \mathrm{C}, 150 \mathrm{rpm}, \mathrm{RT}\right)$. After 5 days for yeast and 3 days for fungi, biomass was separated by centrifugation $\left(10 \mathrm{~min}, 4,000 \mathrm{rpm}, 4^{\circ} \mathrm{C}\right)$. The biomass was pooled and washed twice with buffer (Tris $5 \mathrm{mmol} / \mathrm{L}$, $\mathrm{pH}$ 7.5).

Disintegration procedure

Samples of washed biomass $(6.5 \mathrm{~g})$ were suspended in $15 \mathrm{~mL}$ of cold buffer (Tris $50 \mathrm{mmol} / \mathrm{L}, \mathrm{pH} 7.5$ ) and disintegrated according to the procedures described below. The efficiency of cell disruptions was monitored by measuring two parameters: concentration of the soluble proteins in cell-free extract and the activity of the glucose-6-phosphate dehydrogenase (G6PD) assignment. All the experiments were carried out independently in triplicate.

Disintegration methods

\section{Bead mill}

The microbial cells were mixed either with glass (diameter, $0.5 \mathrm{~mm}$ ) or zirconia (diameter, $0.7 \mathrm{~mm}$ ) beads and disintegrated using a BioSpec BeadBeater (model 1107900) under cooling on ice. The total time of disintegration was $3 \mathrm{~min}$ in different cycles $(30 \mathrm{~s}$ or $1 \mathrm{~min}$ of disruption and $2 \mathrm{~min}$ of cooling or $3 \mathrm{~min}$ of continuous process). After the separation of beads by decantation, cell homogenates were centrifuged $\left(6,500 \mathrm{rpm}, 15 \mathrm{~min}, 4^{\circ} \mathrm{C}\right.$; Hettich Universal 16 Zentrifugen) and the supernatant was analyzed.

\section{Sonication}

Sonication was performed using a Torbeo Ultrasonic Processor (Fisher Scientific) device to provide continuous application of acoustic waves for 11 or $30 \mathrm{~s}$. The sonication was then interrupted and the suspended cells cooled in an ice bath for $2 \mathrm{~min}$, and the next sonication cycle was then performed. The total time of sonication was $1,2,3.5$, or 
$5 \mathrm{~min}$. The homogenate was centrifuged $(6,500 \mathrm{rpm}$, $15 \mathrm{~min}, 4^{\circ} \mathrm{C}$; Hettich Universal 16 Zentrifugen) and the supernatant analyzed.

\section{Chemical disintegration}

The sample of biomass was suspended in an appropriate water solution of detergents (Triton X-100, CTAB, Tween 80, SDS) and incubated with shaking in room temperature. Detergent concentrations were as follows: $0.1 \%, 0.25 \%$, $0.5 \%$, and $1 \%$ for $R$. gracilis; $0.5 \%, 1 \%, 1.5 \%$, and $5 \%$ for $P$. citrinum and A. fumigatus. After the incubation period (5 or $20 \mathrm{~min}$ for yeast and 20 or $40 \mathrm{~min}$ for molds), the mixture was clarified by centrifugation $(6,500 \mathrm{rpm}, 15 \mathrm{~min}$, $4^{\circ} \mathrm{C}$; Hettich Universal 16 Zentrifugen) and the supernatant analyzed.

In the case of organic solvent treatment, microbial cells were suspended in $20 \mathrm{~mL}$ of Tris buffer $(50 \mathrm{mmol} / \mathrm{L}$, $\mathrm{pH}$ 7.5) and the mixture with the addition of $2 \mathrm{~mL}$ of toluene was shaken for $2 \mathrm{~h}$; subsequently, the cells were separated by centrifugation and the cell-free extract was analyzed.

\section{Osmotic shock}

Microbial cells were suspended in $20 \mathrm{~mL}$ of hypertonic solution $(50 \mathrm{mmol} / \mathrm{L}$ Tris- $\mathrm{HCl}$ buffer, $\mathrm{pH} 7.5$, containing $10 \mathrm{mmol} / \mathrm{L}$ EDTA and $30 \%(w / v)$ sucrose) and gently shaken for $20 \mathrm{~min}$. After that cell suspension was centrifuged and the pellet was disintegrated by suspending in $20 \mathrm{~mL}$ of $10 \mathrm{mmol} / \mathrm{L} \mathrm{MgCl}{ }_{2}$ over $20 \mathrm{~min}$, the cells were removed by centrifugation and the supernatant was analyzed.

\section{Analytical methods}

\section{Protein assay}

Soluble protein concentrations in clarified supernatants were estimated by the Bradford method using bovine serum albumin as the standard (Bradford 1976).

\section{Enzyme assay}

The activity of the intracellular enzyme, glucose-6phosphate dehydrogenase (E.C. 1.1.1.49), was determined by the method described by Bergmeyer (1983). Changes in absorption at $340 \mathrm{~nm}$ were monitored over a period of $10 \mathrm{~min}$ on UV/Vis Spectrometer (Varian Cary $100 \mathrm{Bio}$ ). Total activity of the crude extracts was given as the specific activity of the enzyme and was expressed in units per milligram of the total amount of proteins, where "U" is defined as $1 \mu \mathrm{mol}$ NADPH formed per minute.

\section{Results}

To establish the most efficient method of fungal cell lysis, three morphologically different fungal species-A. fumigatus, P. citrinum, and Rhodothorula gracilis - were subjected to various disruption protocols. The applied procedures imply the following results.

\section{Sonication}

Ultrasonication is a common mechanical cell disruption method based on the high shear created by a highfrequency ultrasound (above $16 \mathrm{kHz}$ ). The level of released proteins and the activity of G6P dehydrogenase served as an indicator of the mildness of the process. In the case of the $P$. citrinum strain, an 11-s sonication cycle resulted in the highest concentration of the released proteins, but the level of specific activity of G6P dehydrogenase was the best for a longer sonication cycle, $30 \mathrm{~s}$ (Table 1). In contrast, the most suitable way for the disintegration of $A$. fumigatus cells was sonication with 11-s cycles and an overall operation time of $3.5 \mathrm{~min}$. It resulted in a high level of released proteins and allowed obtaining high specific activity of G6P dehydrogenase in the crude extract (Table 1). Similarly, the same operating conditions (11-s cycles and $3.5 \mathrm{~min}$ of process time) were the most suitable for the disintegration of $R$. gracilis yeast (Table 1).

\section{Bead mill}

The amount of proteins released from the cells of the Aspergillus strain was comparable to the values obtained by the sonication procedures. The short time of disintegration (30 s) and the use of smaller glass beads seemed to be optimal for allotted aims (Table 1). The most effective protocol for the disintegration of $P$. citrinum biomass seemed to be the procedure using a 30 -s operating time and the use of $0.7-\mathrm{mm}$ zirconium beads. In the case of Rhodotorula biomass, the level of obtained soluble proteins in the crude extracts disintegrated with zirconia beads was very low compared with the procedures in which glass beads of a smaller size were used. In turn, the highest specific activity of G6P dehydrogenase in the crude extract was achieved with the application of zirconia beads within the overall operating time of $3 \mathrm{~min}$ (Table 1).

\section{Chemical treatment}

The application of Triton X-100, which is a non-ionic type of detergent recommended for permeabilization and/or lysis of cell walls, was found to be ineffective for fungi (data not shown). In the case of P. citrinum, the activity of G6P dehydrogenase in the cell-free extracts was not found. The 


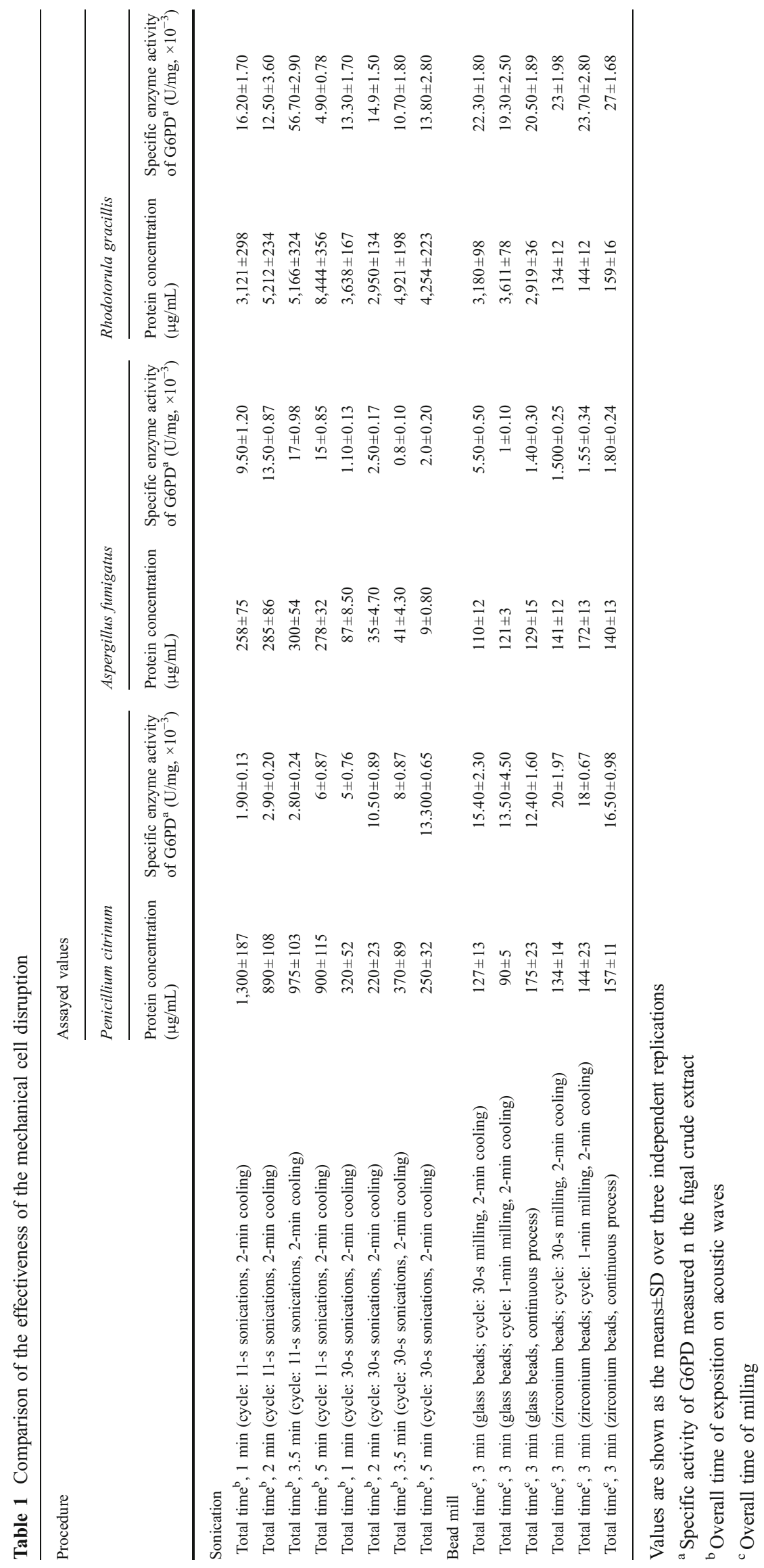


application of this detergent at a $5 \%$ concentration for the disintegration of $A$. fumigatus led to a very low level of specific activity of the model enzyme $\left(1.46 \pm 0.13 \times 10^{-5} \mathrm{U} /\right.$ $\mathrm{mg}$ of proteins). The procedure based on Tween 80 was more effective for the tested molds. The best results were obtained for $P$. citrinum $\left(7.33 \pm 0.27 \times 10^{-5} \mathrm{U} / \mathrm{mg}\right.$ of proteins) when using $1.5 \%$ of Tween 80 for $40 \mathrm{~min}$ of treatment. On the other hand, for A. fumigatus, the G6P dehydrogenase activity was $3.8 \pm 0.17 \times 10^{-4} \mathrm{U} / \mathrm{mg}$ of protein, with $0.5 \%$ of detergent concentration and $40 \mathrm{~min}$ of the process. Both non-ionic detergents were useless for $R$. gracilis. Increasing the detergent concentration (up to $5 \%$ ) resulted in the release of very high levels of total proteins from the cells of the Penicillium and Aspergillus strains (up to 7.5 and $12.3 \mathrm{mg} / \mathrm{mL}$, respectively). Unfortunately, only in the case of P. citrinum did the cell-free extract show the required specific activities of G6P dehydrogenase $-3.44 \pm 0.32 \times 10^{-5} \mathrm{U} / \mathrm{mg}$ of proteins $(0.5 \%, 40 \mathrm{~min})$ and $1.4 \pm 0.09 \times 10^{-5} \mathrm{U} / \mathrm{mg}$ of proteins $(1.5 \%, 40 \mathrm{~min})$. CTAB disintegration of yeast cells resulted in a low level of total proteins released (data not shown), and the most effective procedure appeared to be with $0.1 \%$ of detergent solution. Extending the time of incubation of the cells with detergents (from 5 to $20 \mathrm{~min}$ ) allowed increasing the value of specific activities of the model enzyme from $1.62 \pm 0.56 \times 10^{-3}$ up to $2.23 \pm 0.13 \times 10^{-3} \mathrm{U} /$ $\mathrm{mg}$ of proteins. The effects of anionic detergents on the microorganisms were also investigated using SDS as a model. The procedures based on the application of $0.5 \%$ SDS solution for molds and $0.1 \%$ for yeasts allowed detecting the specific activities of the model dehydrogenase in crude extracts. In the case of $P$. citrinum, after $40 \mathrm{~min}$ of incubation, the value of specific activity was $2.5 \pm 0.06 \times$ $10^{-4} \mathrm{U} / \mathrm{mg}$ of proteins, for $A$. fumigatus was $1.2 \pm 0.08 \times$ $10^{-4} \mathrm{U} / \mathrm{mg}$ of proteins $(20 \mathrm{~min}$ ), and for $R$. gracilis was $4.04 \pm 0.23 \times 10^{-3} \mathrm{U} / \mathrm{mg}$ of proteins $(20 \mathrm{~min})$. Also, the influence of toluene on the cohesion of the cell wall of the microorganisms was examined. The release of a very low amount of the proteins from the cells was observed, and there was no detectable activity of the model dehydrogenase in crude fungal extracts.

Osmotic shock

The disintegration of fungi with this method failed (data are not shown).

\section{Discussion}

The overriding purpose of this study was to set up unique, effective, and repetitive disruption protocols for particular fungal species. The tested fungi have been chosen because of their industrial and/or medical importance. Rhodotorula strains are known for the intracellular production of useful amino acid oxidases (Kuan et al. 2008) and $\beta$-carotene (Vijayalakshmi et al. 2001). Secondary metabolites produced inside the cells of $A$. fumigatus and P. citrinum are also of commercial interest (Du et al. 2010; Chen et al. 2011; Malmstrom et al. 2000; Lim et al. 2007; Singh et al. 2011). Additionally, molds like A. fumigatus are widely considered as a hazard contaminant of food and human pathogen (Debeaupuis et al. 1997; Denning 1998). Molecular methods of detecting fungal pathogen in clinical or food samples require simple and fast methods that sufficiently lyse fungal cells.

The fungal wall structure is highly dynamic, changing constantly during cell division, growth, and morphogenesis. The specific composition and mechanical properties of the cell wall are varied not only between genera but also within closely related species. Moreover, this protective layer could change with growth conditions and genetic modifications (Firon et al. 2004; Klis et al. 2006). Thus, in the case of the sonication methods, most of the ultrasound energy, which is absorbed by cell suspension, appeared as heat; hence, temperature control is crucial and obligatory. Besides the cell types, the appropriate time of exposure of the biological material to the ultrasound is also a critical parameter influencing the activity of the intracellular compounds. In the case of $P$. citrinum strain, the prolongation of sonication cycles from 11 to $30 \mathrm{~s}$ admittedly resulted in the decrease of the amount of released proteins, but allowed obtaining a higher level of specific activity of G6P dehydrogenase in the crude extract (Table 1), suggesting the existence of a lower thermal stress. In contradiction, for the A. fumigatus cells, the short period of sonication was appropriate (11-s cycles and overall operation time of $3.5 \mathrm{~min}$ ), giving as well the extract with a high level of released proteins and a high specific activity of G6P dehydrogenase. The level of proteins released under variable conditions of ultrasound disruption procedures is much higher in the case of yeast cells than molds. This can be simply explained by the different strengths and structures of the fungal cell walls which comprised glycoproteins and polysaccharides, mainly glucan and chitin. Chitin has an enormous tensile strength and significantly contributes to the overall integrity of the cell wall. Chitin microfibrils account for only $1-2 \%$ of the yeast cell walls by dry weight, whereas the cell walls of filamentous fungi, such as Aspergillus, are reported to contain 10-20\% chitin (Bowman and Free 2006). Additionally, G6P dehydrogenases derived from A. fumigatus and $R$. gracilis seemed to be more sensitive to increasing temperature, which made prolongation of the disruption time useless because it caused the significant decrease of the specific activity of the examined model enzyme in the 
crude extract. The observed inactivation of dehydrogenase might also derive from ionization and subsequent free radical formation (Gogate and Kabadi 2009). Application of the bead mill turned out to be effective in the case of the destruction of Penicillium cells. Although the amount of the released proteins was lower, the specific activities of the model enzyme were surprisingly high (up to $20 \pm 1.97 \times$ $10^{-3} \mathrm{U} / \mathrm{mg}$ of proteins). However, in the case of Rhodotorula biomass, the kind of beads and their size were critical parameters, but the results were still unsatisfactory compared with those discussed previously, the sonication procedure. The bead mill is reported to be an efficient technique for rupturing yeast and mold cells compared with its effectiveness toward bacteria (Middelberg 1995). Many operating parameters of milling were used, the most important of which is the design of the stirrer, geometry of the grinding chamber, size of beads, and the temperature. In our case, the disruption method based on the application of BeadBeater ${ }^{\circledR}$ was effective only in the case of $P$. citrinum. Both $A$. fumigatus and $R$. gracilis cells were found to be resistant to milling disruption; thus, the sonication procedures are recommended in these cases. Finally, the chemical treatment led to unsatisfactory results in every experimental attempt. Admittedly, procedures based on detergent treatment, applied for the disintegration of Aspergillus and Penicillum cells, resulted in a high level of released proteins with low or no detectable activity of G6P dehydrogenase in cell-free extracts. The examined detergents inhibited the activity of G6P dehydrogenase and/or forced the conformational changes in the enzyme structure, which influenced the stability of fungal dehydrogenase. In the case of charged detergents, there is also the possibility of a destructive impact which comes from the ionic interaction between enzyme and detergent residues.

Non-mechanical cell disruption methods require less energy, although some of them resulted in the release of side products. However, their application is often limited to processes of a small scale, owing to restrictions of process economics or efficiency. Consequently, they have found limited commercial application.

To sum up, the undertaken efforts allowed elaborating protocols of the cells wall disruption for the examined fungi. The mechanical methods appeared to be the most effective for the disintegration of yeast, $R$. gracilis, and filamentous fungi, A. fumigatus and P. citrinum. Ultrasonication and bead milling led to enzymatically active cellfree extracts, which can be a starting point for the isolation and purification of intracellular components of interest.

Acknowledgments This work was financed from Project "Biotransformations for pharmaceutical and cosmetics industry" no. POIG.01.03.0100-158/09-05, part-financed by the European Union within the European Regional Development Fund for the Innovative Economy.
Open Access This article is distributed under the terms of the Creative Commons Attribution Noncommercial License which permits any noncommercial use, distribution, and reproduction in any medium, provided the original author(s) and source are credited.

\section{References}

Ablain W, Soulier SH, Causeur D, Gautier M, Baron F (2009) A simple and rapid method for the disruption of Staphylococcus aureus, optimized for quantitative reverse transcriptase applications: application for the examination of Camembert cheese. Dairy Sci Technol 89(1):69-81

Agrawal PB, Pandit AB (2003) Isolation of $\alpha$-glucosidase from Saccharomyces cerevisiae: cell disruption and adsorption. Biochem Eng J 15(1):37-45

Al-Samarrai TH, Schmidt J (2000) A simple method for extraction of fungal genomic DNA. Lett Appl Microbiol 30(1):53-56

Anand H, Balasundaram B, Pandit AB, Harrison STL (2007) The effect of chemical pretreatment combined with mechanical disruption on the extent of disruption and release of intracellular protein from E. coli. Biochem Eng J 35(2):166-173

Balasundaram B, Pandit AB (2001) Significance of location of enzymes on their release during microbial cell disruption. Biotechnol Bioeng 75(5):607-614

Bergmeyer HU (1983) Methods of enzymatic analysis, vol. 2. Verlag Chemie, Weinheim, pp 204-205

Borthwick KAJ, Coakley WT, McDonnell MB, Nowotny H, Benes E, Groschl M (2005) Development of a novel compact sonicator for cell disruption. J Microbiol Meth 60(2):207-216

Bowman SM, Free SJ (2006) The structure and synthesis of the fungal cell wall. Bioessays 28(8):799-808

Bradford MM (1976) A rapid and sensitive method for the quantitation of microgram quantities of protein utilizing the principle of protein-dye binding. Anal Biochem 72:248-254

Chaves-Lopez C, Lanciotti R, Serio A, Paparella A, Guerzoni E, Suzzi G (2009) Effect of high pressure homogenization applied individually or in combination with other mild physical or chemical stresses on Bacillus cereus and Bacillus subtilis spore viability. Food Contr 20(8):691-695

Chen YC, Chen LA, Chen SJ, Chang MC, Chen TL (2004) A modified osmotic shock for periplasmic release of a recombinant creatinase from Escherichia coli. Biochem Eng J 19(3):211-215

Chen L, Liu W, Hu X, Huang K, Wu J, Zhang Q (2011) Citrinin derivatives from the marine-derived fungus Penicillium citrinum. Chem Pharm Bull 59(4):515-517

Corrado M, Rodrigues KF (2004) Antimicrobial evaluation of fungal extracts produced by endophytic strains of Phomopsis sp. J Basic Microbiol 44(2):157-160

Dean CR, Ward OP (1992) The use of EDTA or polymyxin with lysozyme for the recovery of intracellular products from $E$. coli. Enzym Microb Tech 6(2):133-138

Debeaupuis JP, Sarfati J, Chazalet V, Latge JP (1997) Genetic diversity among clinical and environmental isolates of Aspergillus fumigatus. Infect Immun 65(8):3080-3085

Denis C, Morancais M, Gaudin P, Fleurence J (2009) Effect of enzymatic digestion on thallus degradation and extraction of hydrosoluble compounds from Grateloupia turuturu. Bot Mar 52(3):262-267

Denning DW (1998) Invasive aspergillosis. Clin Infect Dis 26(4):781805

Doolan IA, Wilkinson MG (2009) Comparison of the effects of various attenuation methods on cell permeability and accessibility of intracellular enzymes in Lactococcus lactis strains. Int Dairy J 19(4):215-221 
Doucha J, Livansky K (2008) Influence of processing parameters on disintegration of Chlorella cells in various types of homogenizers. Appl Microbiol Biotechnol 81(3):431-440

Du L, Zhang G, Zhu T, Ai J, Gu Q (2010) Novel carbon-bridged citrinin dimers from a volcano ash-derived fungus Penicillium citrinum and their cytotoxic and cell cycle arrest activities. Tetrahedron 66(47):9286-9290

Engler CR (1985) Disruption of microbial cells in comprehensive biotechnology. In: Moo-Young M, Cooney CL (eds) Comprehensive biotechnology. Pergamon, UK, pp 305-324

Firon A, Lesage G, Bussey H (2004) Integrative studies put cell wall synthesis on the yeast functional map. Curr Opin Microbiol 7:617-623

Fonesca LP, Cabral JMS (2002) Penicillin acylase release from Escherichia coli cells by mechanical cell disruption and permeabilization. J Chem Technol Biotechnol 77(2):159-167

Garcia FAP (1993) Cell wall disruption. In: Kennedy JF, Cabral JMS (eds) Recovery process for biological materials. Wiley, New York, pp 47-69

Geciova J, Bury D, Jelen P (2002) Methods for disruption of microbial cells for potential use in the dairy industry - a review. Int Dairy J 12(6):541-553

Gogate PR, Kabadi AM (2009) A review of applications of cavitation in biochemical engineering/biotechnology. Biochem Eng J 44 (1):60-72

Harrison STL (1991) Bacterial cell disruption: a key unit operation in the recovery of intracellular products. Biotechnol Adv 9(2):217-240

Heim A, Kamionowska U, Solecki M (2007) The effect of microorganism concentration on yeast cell disruption in a bead mill. J Food Eng 83(1):121-128

Hetherington PJ, Follows M, Dunnill P, Lilly MD (1971) Release of protein from baker's yeast (Saccharomyces cerevisiae) by disruption in an industrial homogenizer. Trans Inst Chem Eng 49:142-148

Ho CW, Tan WS, Yap WB, Ling TC, Tey BT (2008) Comparative evaluation of different cell disruption methods for the release of recombinant hepatitis B core antigen from Escherichia coli. Biotechnol Bioproc Eng 13(5):577-583

Joubert Y, Fleurence J (2008) Simultaneous extraction of proteins and DNA by an enzymatic treatment of the cell wall of Palmaria palmate (Rhodophyta). J Appl Phycol 20(1):55-61

Kelly WJ, Muske KR (2004) Optimal operation of high-pressure homogenization for intracellular product recovery. Bioproc Biosystems Eng 27(1):25-37

Keshavarz-Moore E, Hoare M, Dunnill P (1990) Disruption of baker's yeast in a high-pressure homogenizer. Enzym Microb Tech 12 (3):764-770

Kitamura K (1982) Re-examination of zymolase purification. Agric Biol Chem 446:963-969

Klis FM, Boorsma A, De Groot PWJ (2006) Cell wall construction in Saccharomyces cerevisiae. Yeast 23:185-202

Kuan I, Liao R, Hsieh H, Chen K, Yu C (2008) Properties of Rhodotorula gracilis D-amino acid oxidase immobilized on magnetic beads through His-Tag. J Biosci Bioeng 105(2):110 115

Kuboi R, Umakoshi H, Takagi N, Komasawa I (1995) Optimal disruption methods for the selective recovery of $\beta$-galactosidase from E. coli. J Ferment Bioeng 79(4):335-341
Leuko S, Goh F, Ibanez-Peral R, Burns BP, Walter MR, Neilan BA (2008) Lysis efficiency of standard DNA extraction methods for Halococcus spp. in an organic rich environment. Extremophiles 12(2):301-308

Lim JS, Lee JH, Kang SW, Park SW, Kim SW (2007) Studies on production and physical properties of neo-FOS produced by coimmobilized Penicillium citrinum and neo-fructosyltransferase. Eur Food Res Tech 225(3-4):457-462

Lim CSY, Tung CH, Rosli R, Chong PP (2008) An alternative Candida spp. cell wall disruption method using a basic sorbitol lysis buffer and glass beads. J Microbiol Meth 75(3):576-578

Malmstrom J, Christopherson C, Frisvad JC (2000) secondary metabolites characteristic of Penicillium citrinum, Penicillium steckii and related species. Phytochemistry 54(3):301-309

Middelberg APJ (1995) Process-scale disruption of microorganisms. Biotechnol Adv 13(3):491-551

Ren X, Yu D, Han S, Feng Y (2007a) Thermolysis of recombinant Escherichia coli for recovering a thermostable enzyme. Biochem Eng J 33(1):94-98

Ren X, Yu D, Yu L, Gao G, Siping H, Feng Y (2007b) A new study of cell disruption to release recombinant thermostable enzyme from Escherichia coli by thermolysis. J Biotechnol 129(4):668-673

Ricci-Silva ME, Vitolo M, Abrahao-Neto J (2000) Protein and glucose 6phosphate dehydrogenase releasing from baker's yeast cells disrupted by a vertical bead mill. Process Biochem 35(8):831-835

Sauer T, Robinson CW, Glick BRF (1989) Disruption of native and recombinant $E$. coli in high pressure homogenizer. Biotechnol Bioeng 33(10):1330-1342

Savov V, Kujumdzieva A, Rasheva T (2001) Disintegration of microbial cells. In: Kujumdzieva A (ed) Vocational training in biotechnology innovation and environment protection. National Bank for Industrial Microorganisms and Cell Cultures, Sofia, pp 7-30

Shynkaryk MV, Lebovka NI, Lanoiselle JL, Nonus M, Bedel-Clotour C, Vorobiev E (2009) Electrically-assisted extraction of bio-products using high pressure disruption of yeast cells (Saccharomyces cerevisiae). J Food Eng 92(2):189-195

Singh S, Gogoi BK, Bezbaruah RL (2011) Racemic resolution of some DL-amino acids using Aspergillus fumigatus L-amino acid oxidase. Curr Microbiol 63(1):94-99

Taskova RM, Zorn H, Krings U, Bouws H, Berger RG (2006) A comparison of cell wall disruption techniques for the isolation of intracellular metabolites from Pleurotus and Lepista sp. Zeitschrift fur Naturforschung C-A J Biosci 61(5-6):347-350

Taubert J, Krings U, Berger RG (2000) A comparative study on the disintegration of filamentous fungi. J Microbiol Meth 42(3):225-232

Tkac J, Vostiar I, Mandenius CF (2004) Evaluations of disruption methods for the release of intracellular recombinant protein from Escherichia coli for analytical purposes. Biotechnol Appl Biochem 40(1):83-88

Vijayalakshmi G, Shobha B, Vanajakshi V, Divakar S, Manohar B (2001) Response surface methodology for optimization of growth parameters for the production of carotenoids by a mutant strain of Rhodotorula gracilis. Eur Food Res Technol 213(3):234-239

Yasotha K, Aroua MK, Ramachandran KB, Tan IKP (2006) Recovery of medium-chain-length polyhydroxyalkanoates (PHAs) through enzymatic digestion treatments and ultrafiltration. Biochem Eng J 30(2):206-268 